\title{
Penggunaan Pakan Ikan Berimunostimulan Dalam Meningkatkan Produksi Dan Kualitas Produksi Kelompok Pembudidaya Ikan
}

\author{
The Use of Immunostimulant-Supplemented Food to \\ Increase Production and Production Quality of Fish \\ Cultivator Groups
}

\author{
Henky Manoppo ${ }^{1 *}$, Steelma Vivera Rantung ${ }^{2}$ \\ 1) Staf pengajar pada Program Studi Budidaya Perairan FPIK Unsrat Manado \\ 2) Staf pengajar pada Program Studi Agribisnis Perikanan FPIK Unsrat Manado \\ *Email: $\underline{\text { hmanoppo@yahoo.com }}$
}

\begin{abstract}
Abstrak
Tujuan kegiatan program kemitraan masyarakat (PKM) ini adalah untuk meningkatkan produksi dan kualitas produksi kelompok pembudidaya ikan (pokdakan) melalui pemberian pakan berimunostimulan. Metode kegiatan adalah penyuluhan dan pelatihan yang diberikan melalui tahapan penjelasan, diskusi, praktek dan pendampingan. Pelatihan diberikan dalam bentuk praktek $\mathbf{7 5} \%$ sedangkan teori $25 \%$ dengan alat bantu berupa laptop, infocus, audio visual, boardmarker. Dalam prtaktek, anggota-anggota pokdakan diajarkan cara membuat pakan dengan penambahan imunostimulan. Setelah empat bulan masa pemeliharaan, ikan yang diberi pakan dengan penambahan imunostimulan memiliki bobot tubuh sekitar $30 \%$ lebih besar dari ikan yang tidak diberi imunostimulan. Sebagai kesimpulan, penggunaan pakan dengan penambahan imunostimulan dapat meningkatkan produksi dan kualitas produksi akuakultur.
\end{abstract}

Kata Kunci: Imunostimulan, Ragi Roti, Akuakultur, Pertumbuhan, PKM

Abstract

The purpose of this community partnership program (PKM) was to increase the production and quality of production of fish cultivator groups (pokdakan) through application of immunostimulant-supplemented feed. The method used was counseling and training provided through stages of explanation, discussion, practice and mentoring. Training was given in the form of $75 \%$ practice while the theory was $25 \%$ using tools such as laptops, in focus, audio visuals, board markers. In practice, Pokdakan members were taught how to make feed with the addition of immunostimulants. After four months of rearing, it was found that fish fed with feed supplemented with immunostimulants had a body weight of about $30 \%$ greater than fish that were not given immunostimulants. Thus the use of immunostimulant in fish feed could increase the production and quality of aquaculture production.

Keywords: Aquaculture, Baker's yeast, Immunostimulant, PKM 


\section{PENDAHULUAN}

Kelompok pembudidaya ikan (Pokdakan) Esaan dan Dungarungan yang berkedudukan di Desa Mundung Kecamatan Tombatu Timur, Kabupaten Minahasa Tenggara merupakan kelompok pembudidaya ikan produktif secara ekonomi. Usaha pemeliharaan ikan dilakukan di kolam dan sawah (mina-padi) dengan sistim semi intensif. Sawah sering juga dipakai secara bergantian sebagai kolam dan sebagai sawah yakni setelah padi dipanen, petakan sawah diisi air dan ditebar ikan, selanjutnya setelah ikan dipanen, petakan ditanami padi kembali. Kolam yang digunakan berupa kolam tanah dengan pintu pemasukan dan pengeluaran air terbuat dari bambu atau batang kelapa. Jenis ikan yang dipelihara adalah ikan nila dan ikan mas. Benih ikan yang ditebar kebanyakan berkuran 5-8 cm atau 8-10 cm dengan padat tebar sangat bervariasi tergantung pada jumlah benih yang dibeli. Benih ikan biasanya didatangkan dari Balai Pengembangan dan Pembinaan Pembudidayaan Ikan (BP3I) Tateli yang berjarak sekitar $70 \mathrm{~km}$, atau dari Balai Budidaya Air Tawar Tatelu yang berjarak kurang lebih $120 \mathrm{~km}$ dari desa Mundung. Panen hasil biasanya dilakukan secara sedikit demi sedikit tergantung pada kebutuhan keluarga atau permintaan konsumen, dan biasanya dijual pada pedagang pengumpul atau di pasar lokal setempat. Satu musim tanam berlangsung selama 4 bulan dengan produksi hanya sekitar $600 \mathrm{~kg}$.

Masalah utama yang sering dihadapi pembudidaya ikan adalah seringnya terjadi serangan penyakit terutama yang disebabkan oleh bakteri Aeromonashydrophila, Streptococcus sp. dan virus KHV yang menyebabkan mortalitas 80-100\%. Akibatnya banyak pembudidaya yang mengalami kerugian ekonomi yang cukup besar. Masalah kedua adalah harga pakan (pelet) yang tinggi. Di daerah ini, harga pakan ikan saat ini mencapai Rp. 10.000 per kg. Dalam usaha pemeliharaan ikan, biaya pakan mencapai $60 \%$ dari total biaya produksi. Dengan tingginya harga pelet maka banyak pembudidaya ikan tidak lagi memberikan pelet pada ikan, dan kalaupun 
ada, hanya diberikan satu kali dalam sehari. Kebanyakan pembudidaya hanya memberi pakan berupa jagung, singkong atau sisa-sisa makanan rumah tangga. Praktek ini tentu saja menghasilkan pertumbuhan ikan yang kurang baik dengan mutu yang jelek, produksi rendah sehingga keuntungan yang diperoleh, jika ada, hanya sedikit. Tujuan kegiatan Program Kemitraan Masyarakat (PKM) ini adalah untuk meningkatkan produksi dan kualitas produksi pokdakan melalui penggunaan pakan berimunostimulan. Waktu pelaksanaan kegiatan adalah 8 (delapan) bulan. Bulan pertama merupakan tahap persiapan, bulan kedua pelaksanaan pelatihan, dan bulan ketiga sampai bulan kedelapan merupakan tahap pemeliharaan, pendampingan, pemantauan dan evaluasi kegiatan.

\section{METODE PENELITIAN}

\section{Metode Pelaksanaan}

Metode yang digunakan dalam kegiatan PKM ini adalah penyuluhan dan pelatihan. Pelatihan melibatkan tenaga ahli sebagai pelatih dari Fakultas Perikanan dan Ilmu Kelautan yang mempunyai kompetensi di bidang Manajemen Kesehatan Ikan, Teknologi Akuakultur, Nutrisi dan Pakan Ikan, dan Manajemen Usaha. Peserta pelatihan adalah seluruh anggota dari kedua kelompok pembudidaya mitra yang merupakan kelompok target.

Penyuluhan dan pelatihan diberikan melalui tahapan penjelasan, diskusi, praktek dan pendampingan. Dengan proses ini maka setiap anggota pokdakan dan keluarganya akan mendengar, mengetahui, mencoba, menerima, dan mampu menjalankan usahanya. Pelatihan diberikan dalam bentuk praktek 75\% sedangkan teori 25\%. Proses pelatihan menggunakan alat bantu berupa laptop, infocus, audio visual, boardmarker. Dengan metode diskusi maka terjadi interaksi antara pelatih/instruktur dengan kelompok maupun interaksi antar anggota kelompok untuk mendiskusikan topik yang diberikan, masalah yang 
dihadapi, serta mendiskusikan solusi terhadap berbagai permasalahan yang dihadapi.

Untuk keperluan praktek, setiap kelompok diberikan bantuan berupa benih ikan nila dan ragi roti sebagai sumber imunostimulan dan bahan-bahan untuk formulasi pakan (tepung ikan, tepung kedele, tepung jagung, tepung kelapa, dedak padi, tapioka, top mix), alat penepung, alat cetak pelet, dan lain-lain. Waktu pelaksanaan kegiatan adalah 8 (delapan) bulan. Bulan pertama merupakan tahap persiapan, bulan kedua pelaksanaan pelatihan, dan bulan ketiga sampai bulan kedelapan merupakan tahap pemeliharaan, pendampingan, pemantauan dan evaluasi kegiatan.

Masalah tingginya serangan penyakit diatasi melalui penggunaan pakan berimunostimulan ragi roti. Penerapan teknologi ini dilakukan dengan memberi penyuluhan dan pelatihan cara pembuatan pakan berimunostimulan ragi roti. Metode ini menerapkan hasil penelitian yang sudah dilakukan sebelumnya oleh Manoppo dan Kolopita (2016a ${ }^{\text {2016 }}$ ) dan Manoppo et al. (2015) dimana penambahan ragi roti 5-10 g/kg pakan dapat meningkatkan pertumbuhan, sistim imun nonspesifik serta meningkatkan resistensi ikan setelah diuji tantang dengan bakteri patogen dengan kelangsungan hidup mencapai 76,6\%. Sedangkan ikan yang tidak diberi ragi roti hanya memiliki kelangsungan hidup 50\% .

\section{Partisipasi Mitra}

Kedua mitra pokdakan merupakan kelompok yang aktif menjalankan usaha budidaya ikan. Dengan demikian maka sarana dan prasarana usahaseperti kolam ikan dan peralatan kerja sudah tersedia untuk keperluan PKM ini. Tenaga kerja juga sudah tersedia karena anggotaanggota pokdakan merupakan pelaku kegiatan. Biaya operasi lainnya seperti biaya pemeliharaan kolam, upah tenaga kerja sudah tersedia. Secara keseluruhan, partisipasi mitra dalam kegiatan PKM ini sebagai berikut: 
1. Kolam usahanya dijadikan sebagai bahan praktek sehingga setiap anggota kelompok terlibat secara aktif. Dalam hal ini, kelompok mitra diharapkan dapat mempraktekkan sendiri langsung di kolam pemeliharaan dengan dibimbing dan didampingi tim pelaksana. Tim pelaksana selanjutnya akan melakukan pendampingan, pemantauan dan evaluasi setiap bulan sampai kegiatan ini berakhir

2. Pembudidaya ikan dilibatkan sebagai anggota tim dalam setiap kegiatan kerja. Tujuannya agar masyarakat dan kelompok pembudidaya ikan ikut berpartisipasi langsung dalam kegiatan tersebut mulai awal sampai akhir. Dengan demikian masyarakat merasa bertanggung jawab dan merasa memiliki sehingga kegiatan PKM bisa lebih efektif. Dengan cara demikian maka diharapkan pembudidaya ikan dapat menerapkan iptek yang diperolehnya kepada masyarakat pembudidaya ikan lainnya.

\section{Evaluasi Pelaksanaan dan Keberlanjutan Program}

Evaluasi dan pemantauan pelaksanaan program kegiatan PKM dilakukan secara rutin setiap bulan sekali sejak bulan ketiga (tahap pemeliharaan) disertai dengan pedampingan sampai pada bulan ke delapan sebagai akhir dari kegiatan PKM. Untuk keberlanjutan program setelah kegiatan berakhir maka masyarakat pembudidaya dapat terus berdiskusi dengan tim pelaksana untuk membahas setiap masalah/hambatan serta mencari solusi yang dibutuhkan untuk memecahkan setiap masalah yang dihadapi. Komunikasi dan diskusi antara anggota-anggota pokdakan dengan tim pelaksana program dapat dilakukan melalui telepon, email, WA, atau melalui perkunjungkan ke lokasi pokdakan atau ke kampus dimana tim pelaksana berkantor.

\section{Analisis data}

Data hasil kegiatan PKM ini dianalisis secara deskriptif kuantitatif maupun kualitatif. 


\section{Hasil dan Pembahasan}

Kegiatan PKM diikuti oleh seluruh anggota Pokdakan Dungarungan dan Esaan. Selain itu, beberapa anggota masyarakat pembudidaya dari Pokdakan lain yang berada di Kecamatan Tombatu Timur juga ikut sebagai pendengar. Hal ini mengindikasikan bahwa masyarakat pembudidaya ikan di daerah ini sangat antusias dan terbuka ntuk menerima informasi mengenai teknologi budidaya ikan. Dalam kegiatan PKM ini hadir pula Kepala Dinas Perikanan dan Kelautan Kabupaten Minahasa Tenggara yang memberi sambutan dan pengarahan kepada anggota-anggota pokdakan peserta kegiatan PKM serta sekaligus membuka secara resmi kegiatan penyuluhan dan pelathan ini.

Materi penyuluhan dan pelatihan diberikan oleh tenaga ahli dari Program Studi Budidaya Perairan dan Progran Studi Agribisnis Perikanan, Fakultas Perikanan dan Ilmu Kelautan Unsrat. Setiap peserta diberi alat tulis menulis dengan tujuan agar selain mendengar, pembudidaya dapat mencatat semua informasi penting yang diberikan. Selain itu, setiap kelompok diberikan bahan baku pembuatan pakan ikan untuk digunakan dalam praktek. Materi disampaikan melalui tahapan penjelasan, kemudian diskusi/tanya jawab dan diikuti dengan ptaktek. Peserta sangat aktif berdiskusi dan mengajukan beberapa pertanyaan kepada nara sumber. Materi yang disampaikan meliputi: Manajemen Kesehatan Ikan, Teknologi Formulasi Pakan Ikan, Teknik Budidaya Ikan dan Manajemen Pemasaran dan Pembukuan yang dibutuhkan untuk menunjang perencanaan dan pengembangan usaha.

Selesai penjelasan dan diskusi, nara sumber mendemonstrasikan cara pembuatan pakan ikan kepada peserta. Selanjutnya, anggota-anggota pokdakan mengerjakannya sendiri dengan didampingi tim pelaksana. Dengan cara demikian maka setiap anggota pokdakan menjadi terampil dan mampu membuat pakan ikan dengan bahan baku yang berasal dari daerah setempat. 
Selesai pembekalan (melalui penyuluhan dan pelatihan), kedua pokdakan peserta diberi bantuan benih ikan nila masing-masing sebanyak 10.000 ekor untuk memberi kesempatan kepada kelompok mempraktekkan secara langsung bekal teknologi budidaya yang sudah mereka peroleh lewat penyuluhan/pelatihan. Ikan ditebar dengan kepadatan 10 ekor/m2 pada dua buah kolam yaitu kolam A dan kolam B. Kolam pemeliharaan/praktek yang digunakan adalah kolam milik kelompok, sedangkan tenaga yang digunakan untuk proses pemeliharaan ikan, perawatan kolam dan lain-lain adalah anggota-anggota kelompok itu sendiri sehingga tidak membutuhkan biaya sewa kolam dan biaya tenaga kerja.

Setelah benih ikan ditebar, anggota-anggota kelompok diberi pelatihan tentang cara mencampurkan bahan iminostimulan ragi roti ke dalam pakan pelet. Pemberian pakan berimunostimulan bertujuan untuk meningkatkan sistim kekebalan tubuh ikan sehingga ikan lebih tahan terhadap serangan penyakit. Selain itu, penambahan ragi roti dalam pakan dapat mamacu pertumbuhan ikan yang dipelihara.

Pakan berimunostimulan diberikan pada ikan selama 30 hari pertama, selanjutnya ikan diberi pakan tanpa penambahan imunostimulan. Ikan di kolam A diberi pakan yang ditambahkan imunostimulan sedangkan ikan di kolam $B$ hanya diberi pakan pelet tanpa penambahan imunostimulan. Dosis pemberian pakan adalah 5\%/berat badan/hari dengan frekuensi pemberikan 2 kali sehari yakni pagi dan sore hari. Selama masa pemeliharaan, tim pelaksana terus melakukan monitoring dan pendampingan agar praktek pemeliharaan ikan berlangsung dengan baik. Setelah 4 bulan pemeliharaan, ikan yag diberi imunostimulan ragi roti memiliki berat rata-rata sekitar $200 \mathrm{~g}$ (1 kg = 5 ekor) sedangkan ikan yang tidak diberi roti beratnya 166 - $142 \mathrm{~g}$ (1 kg = 6-7 ekor). Jadi berat ikan yang diberi pakan dengan penambahan imunostimulan mencapai rata-rata sekitar 30\% lebih besar dari ikan yang tidak diberi imunostimulan. Selama 
masa pemeliharaan juga tidak terjadi serangan penyakit pada ikan yang dipeihara.

Ragi roti selain meningkatkan sistim imum ikan, juga dapat memacu pertumbuhan ikan. Ragi roti mengandung bahan-bahan imunostimulan terutama $\beta$-1-3 glucan (50-60\%) dan nukleotida (purin dan pirimidin) yang dapat merangsang peningkatan sistim kekebalan tubuh ikan dan krustase (Babu et al., 2013; Sajeevan et al., 2009; Abdel-Tawwab et al., 2008; Li and Galtin, 2003, 2006). Ragi roti juga banyak tersedia di pasaran sehingga mudah diperoleh dengan harga yang murah. Hasil penelitian Manoppo dan Kolopita (2015, 2016a) mendapatkan bahwa penggunaan ragi roti dalam pakan ikan mampu mempercepat pertumbuhan ikan. Hasil penelitian tersebut mendapatkan bahwa ikan nila (berat rata-rata 9 g) yang diberi pakan dengan penambahan ragi roti $5-10 \mathrm{~g} / \mathrm{kg}$ pakan dan diberikan selama empat minggu memiliki berat tubuh $24 \mathrm{~g}$ atau 38,49\% lebih besar dari ikan yang tidak diberi ragi roti yang hanya sebesar 17,33 g. Kelangsungan hidup ikan yang diinfeksi dengan A. hydrophila mencapai 76,6\% sedangkan ikan yang tidak diberi ragi roti hanya memiliki kelangsungan hidup 50\%. Hasil penelitian lain melaporkan melaporkan bahwa ragi roti mampu meningkatkan resistensi ikan nila dan ikan mas terhadap infeksi bakteri $A$. hydrophila (Biswas et al., 2012), dan ikan ), ikan Labeo rohita (Tewary and Patra, 2011). Ragi roti memacu pertumbuhan karena nukleotida yang terkandung dalam ragi roti dapat meningkatkan napsu makan ikan sehingga pengambilan pakan dan efisiensi pakan meningkat.

\section{Kesimpulan}

1. Pengunaan imunostimulan ragi roti dalam kegiatan budidaya ikan dapat meningkatkan pertumbuhan dan kelangsungan hidup yang berdampak pada peningkatan produksi dan kualitas produksi.

2. Pengetahuan dan ketrampilan masyarakat pembudidaya ikan meningkat dengan adanya kegiatan PKM. Masyarakat menjadi 
mampu mengatasi permasalahan yang dihadapi dalam menjalankan usaha budidaya ikan yang pada akhirnya dapat merangsang pembembentukan kelompok-kelompok pembudidaya ikan yang mandiri secara ekonomi.

\section{Ucapan Terima Kasih}

Penulis menyampaikan terima kasih kepada Kemenristek Dikti atas dukungan dana sehingga kegiatan PKM ini dapat terlaksana. Ucapan terima kasih juga disampaikan kepada seluruh anggota pokdakan Esaan dan Dungarungan atas partisipasi aktif yang diberikan selama kegiatan PKM ini.

\section{Daftar Pustaka}

Abdel-Tawwab M., Abdel-Rahman A.M., Ismael N.E.M. 2008. Evaluation of commercial live bakers' yeast, Saccharomyces cereviciae as a growth and immunity promoter for fry Nile Tilapia Oreachromis niloticus (L) challenged in situ with Aeromonas hydrophila. Aquaculture 280: 185189.

Babu, D.T., Antony, S.P., Joseph S.P., Bright, A.R., Philip, R. 2013. Marine yeast Candida aquaetextoris S527 as a potential immunostimulant in black tiger shrimp Penaeus monodon. Journal of Invertebrate Pathology. 122: 243-252

Biswas, G., Korenaga, H., Takayama, H., Kono, T., Shimokawa, H., Sakai, M. 2012. Cytokine responses in the common carp, Cyprinus carpio L. treated with baker's yeast extract 356-357: 169-175

Li, P. and Galtin, D.M. 2003. Evaluation of brewers' yeast. (Saccharomyces cereviciae) as a feed supplement for hybrid striped bass (Marone chrysops x M. saxatillis). Aquaculture 219: 681-692.

Li, P. and Galtin D.M. 2006. Nucleotide nutrition in fish: Current 
knowledge and fiture application. Aquaculture 251: $141-152$.

Manoppo, H. dan Kolopita, M. 2015. Pengimbuhan ragi roti dalam pakan meningkatkan respons imun nonspesifik dan pertumbuhan ikan nila. Jurnal Veteriner Vol 16 No 2 (Terakreditasi DIKTI).

Manoppo, H., Tumbol, R.A., Manurung, U.N., 2015. Incorporation of baker's yeast cells as immunostimulant in feed enhance resistance of nile tilapia to Aeromonas hydrophila. International Journal of PharmTech Research Vol.8, No.5, pp 797-802

Manoppo, H. dan Kolopita, M. 2016a. The use of baker's yeast to promote growth of carp (Cyprinus carpio L). International journal of PhamTech Research Vol. 9 No. 9: 415-420

Manoppo, H. dan Kolopita, M., 2016b. Penggunaan ragi roti (Saccharomyces cerevisiae) sebagai imunostimulan untuk meningkatkan resistensi ikan mas (Cyprinus carpio L) terhadap infeksi bakteri Aeromonas hydrophila.Jurnal Budidaya Perairan. Vol. 4 No. 3: 37-47

Sajeevan, T.P, Philip, R., Singh, I.S.B., 2009. Dose/frequency: a critical factor in the administration of glucan as immunostimulant to Indian white shrimp Fenneropenaeus indicus. Aquaculture 287: 248-252

Tewary, A. and Patra, B.C. 2011 Oral administration of baker's yeast (Saccharomyces cerevisiae) acts as a growth promoter and immunomodulator in Labeo rohita (Ham.). Journal of Aquaculture Research and Development 2:109 